\title{
Novel Telechelic 2-Methyl-2-Bromopropionate Terminated Polyurethane Macroinitiator for the Synthesis of ABA type Tri-block Copolymers through Atom Transfer Radical Polymerization of Methyl Methacrylate
}

\author{
By Hemant VERMA and Tharanikkarasu KANNAN*
}

Novel telechelic 2-methyl-2-bromopropionate terminated polyurethane macroinitiator was synthesized and used further to polymerize methyl methacrylate to yield poly(methyl methacrylate)-block-polyurethane-block-poly(methyl methacrylate) triblock copolymers through atom transfer radical polymerization. Number-average molecular weight $\left(M_{\mathrm{n}}\right)$ was increased linearly with increasing polymerization time and conversion. Molecular weight distribution becomes narrower as the polymerization time increases and theoretical $M_{\mathrm{n}}$ values of the tri-block copolymers were comparable to the experimental $M_{\mathrm{n}}$ values. Structures of the macroinitiator and the tri-block copolymers were confirmed by ${ }^{1} \mathrm{H} N M R,{ }^{13} \mathrm{C}$ NMR and FT-IR spectroscopic techniques. Mole percentage of poly(methyl methacrylate) in the triblock copolymers was calculated using ${ }^{1} \mathrm{H}$ NMR spectroscopy and was found to be comparable with the gel permeation chromatography results. Presence of two phases in the tri-block copolymers has been confirmed through differential scanning calorimetric studies.

KEY WORDS: ATRP / Block Copolymers / Poly(methyl methacrylate) / Polyurethanes /

Living anionic polymerization was first discovered by Szwarc, ${ }^{1}$ where polymer chain propagation took place without chain breaking reactions such as chain transfer and chain termination. As a result polymers with defined molecular weight, narrow molecular weight distribution (MWD) and desired end groups were achieved through this method. But it requires stringent experimental conditions and highly pure monomers and solvents. On contrary, free radical polymerization is used widely to polymerize more than $70 \%$ of vinyl and acrylate monomers in industries but it has poor control over degree of polymerization, MWD and end functionalization during polymerization. In recent years, the idea of introducing livingness in free radical polymerization was proposed and it was termed as controlled radical polymerization (CRP). ${ }^{2}$ As the conversion increases $M_{\mathrm{n}}$ also should increase linearly in any living polymerizations. ${ }^{2}$ In conventional radical polymerization there is no linear increase of molecular weight with the conversion. ${ }^{2}$ Hence in all CRP routes linear increase of molecular weight with conversion should takes place to show that they are following living polymerization mechanism. ${ }^{2}$ Indeed different types of CRP techniques have been reported which facilitated the synthesis of broad variety of polymeric materials with predetermined molecular weight, narrow MWD and desired chain end groups. CRP was achieved through iniferter (initiation transfer termination), ${ }^{3}$ stable nitroxide radicals, ${ }^{4}$ triazolinyl radicals, ${ }^{5}$ organo-bismuthine, ${ }^{6}$ organotellurium, ${ }^{7}$ organo-cobalt, ${ }^{8}$ organo-stilbene, ${ }^{9}$ alkyl-9-BBN, ${ }^{10}$ reversible addition-fragmentation-chain transfer (RAFT), ${ }^{11}$ degenerative chain transfer by alkyl iodide, ${ }^{12}$ and atom transfer radical polymerization (ATRP). ${ }^{13,14}$ All the CRP methods include activation and deactivation steps with their respective rate constants, $k_{\text {act }}$ and $k_{\text {deact }}$ respectively and $k_{\text {deact }}$ is higher in all the cases to get controlled radical polymerization of monomers. ATRP exploits organic halide (haloalkanes, ${ }^{13,15}$ haloketones ${ }^{16}$ halonitriles, ${ }^{17}$ haloamide, ${ }^{18}$ haloesters,${ }^{16}$ and arenesulphonyl halides, ${ }^{19}$ ) as an initiator and transition metal in their lower oxidation state $\left(\mathrm{Cu}(\mathrm{I}),{ }^{20} \mathrm{Fe}(\mathrm{II}),{ }^{21,22} \mathrm{Ni}(\mathrm{II}),{ }^{23}\right.$ $\mathrm{Ru}(\mathrm{II}),{ }^{13} \mathrm{Mo}(\mathrm{III}),{ }^{24} \mathrm{Ti}(\mathrm{III}),{ }^{25} \mathrm{Pd}(\mathrm{II}),{ }^{26} \mathrm{Os}(\mathrm{II}),{ }^{27}$ and $\mathrm{Re}(\mathrm{II}),{ }^{28}$ ) complexed with suitable ligand as catalyst to polymerize different monomers. Variety of polymers with different structures and architectures have been prepared through ATRP which includes polymer brushes, ${ }^{29}$ block copolymers, ${ }^{30,31}$ syndiotactic graft copolymers, ${ }^{32}$ star shaped copolymers, ${ }^{33}$ immobilized-polymer, ${ }^{34}$ to mention a few.

Tri-block copolymers have widespread applications in the field of drug delivery and gene targeting because of the high drug-loading capacity of the inner core as well as the unique disposition characteristics in the body. Micelles from these block copolymers form extraordinary core-shell structure. Variety of hydrophilic polymers with flexible nature can be selected as the shell forming segment. Various poly (ethylene glycol) based block copolymeric micelles have been reported in the field drug delivery particularly for the delivery of genes and cytotoxic agents. ${ }^{35-38}$ Here size of the block copolymeric micelles, viruses and lipoproteins are in mesoscopic size range (tens of nanometer size) which is the reason for the interaction. But viruses and lipoproteins have narrow size distribution and hence polymeric micelles should also have narrow size distribution for good interaction. ${ }^{39}$ The narrow size distribution of the polymeric micelle can be achieved when the MWD of 
the polymer or block copolymer is narrow. Narrow MWD can be achieved through controlled radical polymerization. As polyurethanes are important class of polymers that have found many applications as biomaterials on account of their excellent physical properties and relatively good biocompatibility, ${ }^{40}$ synthesis of polyurethane-based tri-block copolymers are attempted in this study. By changing different commercially available polyols, diisocyanates and chain extenders, molecular weight of polyurethanes and their properties can easily be altered. Similarly, by using bromo-terminated polyurethane, controlled incorporation of polymeric blocks at the both the ends of polyurethane can be achieved through ATRP mechanism. The controlled incorporation of vinyl blocks into polyurethane was already achieved through iniferters. ${ }^{41,42}$ Polyurethane-polystyrene multi-block copolymers were synthesized through nitroxide radical mediated CRP, but broad MWD was obtained. ${ }^{43}$ Very recently, polystyrene-block-polyurethane-block-polystyrene ${ }^{44}$ (PSt- $b$-PU- $b$-PSt) tri-block copolymers have been reported through ATRP mechanism in our lab. However, the radicals generated from polyurethane with $-\mathrm{CH}_{2} \mathrm{Br}$ end groups were not more stable and hence broad MWD values were obtained. Therefore in the present investigation, we have synthesized novel telechelic 2-methyl-2bromopropionate terminated polyurethane (MBP-PU-MBP) and used it further as a ATRP macroinitiator to synthesize PMMA- $b$-PU- $b$-PMMA tri-block copolymers using $\mathrm{CuBr}$ as a catalyst and $N, N, N^{\prime}, N^{\prime \prime}, N^{\prime \prime}$-pentamethyldiethylenetriamine (PMDETA) as a ligand. This is a basic study and if this is successful, this method can be used to prepare micelles forming polyurethane-based tri-block copolymers which can be used for drug delivery.

\section{EXPERIMENTAL}

\section{Materials and Methods}

Dibutyltin dilaurate, $\alpha$-bromoisobutyryl bromide, toluene diisocyanate (TDI; mixture of $80 \% \quad 2,4$ and $20 \% \quad 2,6$ isomers), calcium hydride, and PMDETA were used as received from Aldrich, U.S.A. Analytical grade ethylene glycol was purchased from Merck, India refluxed with calcium hydride and then vacuum distilled. The middle portion was used after storing over type $4 \AA$ molecular sieves. Poly(tetramethyleneoxide) glycol (PTMG) of molecular weight 1000 (Aldrich, U.S.A.) was used after drying it by heating at $105^{\circ} \mathrm{C}$ under vacuum for $3 \mathrm{~h}$ just before use. Analytical grade $N, N$-dimethylformamide (DMF; $\mathrm{CDH}$, India) was distilled under reduced pressure and the middle portions were used after storing over type $4 \AA$ molecular sieves. The inhibitor present in methyl methacrylate (MMA; Aldrich, U.S.A.; 99\%) was removed, using conventional method. It was then distilled at reduced pressure and the middle portion was stored at $0-4{ }^{\circ} \mathrm{C}$ until use. $\mathrm{CuBr}$ (Aldrich, U.S.A.; 98\%) was purified using a reported procedure, ${ }^{45}$ and stored under argon atmosphere. All other chemicals used were of analytical grades and were used as received.

\section{Synthesis of 2-hydroxyethyl-2'-methyl-2' -bromopropionate and MBP-PU-MBP}

2-Hydroxyethyl-2'-methyl-2'-bromopropionate (HMB) was prepared from $\alpha$-bromoisobutyryl bromide and ethylene glycol as described previously. ${ }^{46}$

${ }^{1} \mathrm{H} \mathrm{NMR}\left(\mathrm{CDCl}_{3}, \mathrm{ppm}\right): \delta=4.3(\mathrm{t}, 2 \mathrm{H}), 3.85(\mathrm{t}, 2 \mathrm{H}), 3(\mathrm{~s}, 1 \mathrm{H})$, 1.9 (s, 6H).

${ }^{13} \mathrm{C} \mathrm{NMR}\left(\mathrm{CDCl}_{3}, \mathrm{ppm}\right): \delta=172.93,68.33,61.46,56.90$, 31.67 .

MBP-PU-MBP was prepared as follows. Dried PTMG of molecular weight 1000 (20 g, $0.02 \mathrm{~mol})$ was placed in $250 \mathrm{~mL}$ three necked round bottom flask, fitted with a mechanical stirrer, nitrogen inlet, a dropping funnel and heated in an oil bath. When the temperature reached $65^{\circ} \mathrm{C}$, TDI $(6.96 \mathrm{~g}$, $0.04 \mathrm{~mol}$ ) was added drop by drop with stirring. The temperature was then raised to $70^{\circ} \mathrm{C}$ and the reaction was allowed to proceed until the isocyanate content reached half of the initial value (as determined by dibutylamine titration). Then HMB $(8.44 \mathrm{~g}, 0.04 \mathrm{~mol})$ in $15 \mathrm{~mL}$ DMF was added followed by dibutyltin dilaurate $(2 \mathrm{~mol} \%$ of NCO, $0.25 \mathrm{~g}$ ). The reaction was allowed to proceed until complete disappearance of isocyanate group, which was monitored by the Fourier-transform infrared (FT-IR) spectroscopy.

\section{Synthesis of PMMA- $b$-PU- $b$-PMMA Tri-block Copolymers}

For the synthesis of PMMA- $b$-PU- $b$-PMMA tri-block copolymers, first MBP-PU-MBP was dissolved in DMF and known quantities of PMDETA, $\mathrm{CuBr}$ and MMA were added successively. The homogeneous reaction mixture was degassed by three alternate freeze-pump-thaw cycles, sealed under vacuum and placed in a thermo-stated oil bath controlled to $\pm 0.01{ }^{\circ} \mathrm{C}$ for selected time. At the end of the stipulated period, the reaction mixture was removed from the oil bath and the reaction was arrested by dipping in an ice-salt mixture. The resulting solution was poured into a 10-fold excess of methanol and the precipitate was filtered, using sintered-glass crucible, washed with methanol, dried in vacuum, and weighed. The dried samples were washed thoroughly with acetonitrile to remove homo PMMA, if any, from the block copolymers, dried in vacuum, and weighed.

\section{Measurement and Characterization}

Experimental number average $\left(M_{\mathrm{n}}\right)$, weight-average $\left(M_{\mathrm{w}}\right)$ molecular weights and MWD were determined by gel permeation chromatography (GPC) using polymer laboratories GPC 50 integrated system equipped with differential refractometer (RI Detector) and PLgel $5 \mu \mathrm{m}$ MIXED-C column. Tetrahydrofuran was used as an eluent at a flow rate of $1.0 \mathrm{~mL} /$ min and the molecular weight calibrations were done using polystyrene standards. Fourier-transform nuclear magnetic resonance (FT NMR) spectra were recorded on a Bruker DPX-300 NMR instrument using deuterated dimethyl sulfoxide as the solvent and tetramethylsilane as an internal standard. FTIR spectra were recorded as a $\mathrm{KBr}$ pellet on a Nicolet Impact 400 FT-IR spectrophotometer. Differential scanning calorimeter (DSC) was carried out using DSC Q200 instrument (TA 


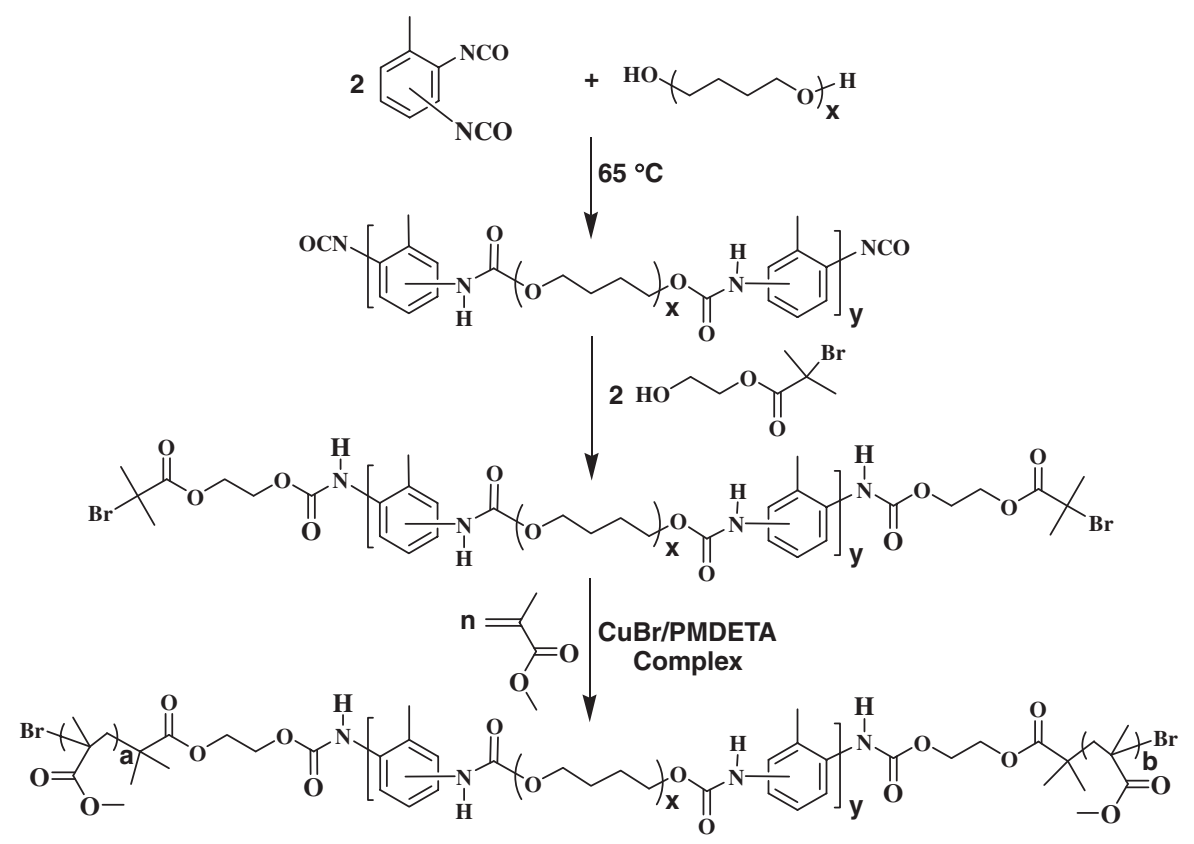

Scheme 1. Synthesis of telechelic 2-methyl-2-bromopropionate terminated polyurethane and PMMA-b-PU-b-PMMA tri-block copolymers.

Table I. Effect of time on ATRP of MMA at $100^{\circ} \mathrm{C}$

\begin{tabular}{|c|c|c|c|c|c|c|c|c|c|}
\hline \multirow{2}{*}{ Code No. } & \multirow{2}{*}{$\begin{array}{l}\text { Time } \\
\text { (min.) }\end{array}$} & \multirow{2}{*}{$\begin{array}{c}\text { Conv. }^{a} \\
(\%)\end{array}$} & \multirow{2}{*}{$\begin{array}{l}\text { Molar } \\
\text { content of } \\
\text { PMMA }^{\mathrm{b}} \\
(\%)\end{array}$} & \multirow{2}{*}{$\begin{array}{l}\text { Molar } \\
\text { content of } \\
\text { PMMA }^{\mathrm{C}} \\
(\%)\end{array}$} & \multirow{2}{*}{$\begin{array}{c}M_{\mathrm{n}} \times 10^{-3} \\
(\mathrm{th})^{\mathrm{d}}\end{array}$} & \multicolumn{3}{|c|}{ GPC results } & \multirow{2}{*}{$\mathrm{fe}^{\mathrm{e}}$} \\
\hline & & & & & & $M_{\mathrm{n}} \times 10^{-3}$ & $M_{w} \times 10^{-3}$ & $M_{\mathrm{w}} / M_{\mathrm{n}}$ & \\
\hline MBP-PU-MBP & 0 & 0 & - & - & - & 3.2 & 4.8 & 1.50 & - \\
\hline POLY 1 & 15 & 6.4 & 118.7 & 134.3 & 5.1 & 7.5 & 12.3 & 1.65 & 0.68 \\
\hline POLY 2 & 30 & 11.7 & 298.5 & 312.5 & 6.7 & 13.2 & 21.3 & 1.62 & 0.50 \\
\hline POLY 3 & 60 & 21.4 & 452.6 & 478.1 & 9.6 & 18.5 & 29.2 & 1.58 & 0.52 \\
\hline POLY 4 & 120 & 39.5 & 723.8 & 762.5 & 15.0 & 27.6 & 41.6 & 1.51 & 0.54 \\
\hline POLY 5 & 180 & 53.4 & 821.2 & 840.6 & 19.2 & 30.1 & 44.5 & 1.48 & 0.63 \\
\hline POLY 6 & 240 & 65.2 & 903.8 & 918.7 & 22.7 & 32.6 & 47.2 & 1.45 & 0.69 \\
\hline
\end{tabular}

${ }^{a}$ Conversion was determined gravimetrically. ${ }^{b}$ Molar content of PMMA was calculated by comparing integration values of the peaks derived for $-\mathrm{CH}_{2}-\mathrm{CH}_{2}$ protons of PTMO and $-\mathrm{CH}_{3}$ protons of PMMA blocks in ${ }^{1} \mathrm{H}$ NMR spectra. ${ }^{43}{ }^{\mathrm{c}}$ Molar content of PMMA was calculated by using $M_{\mathrm{n}}$ values of MBP-PU-MBP and PMMA- $b$-PU- $b$-PMMA derived from GPC. ${ }^{d} M_{\mathrm{n}, \mathrm{th}}=\left(\frac{[\mathrm{MMA}]_{0}}{[\mathrm{MBP}-\mathrm{PU}-\mathrm{MBP}]_{0}} \times\right.$ Conversion $)+M_{\mathrm{n}}$ of MBP-PU-MBP. ${ }^{\mathrm{e}} \mathrm{f}=M_{\mathrm{n}, \mathrm{th}} / M_{\mathrm{n}, \mathrm{GPC}}$. Polymerization conditions: $[M B P-P U-M B P]_{0}=0.5 \mathrm{~g}(0.5 / 3200=0.156 \mathrm{mmol})[P M D E T A]_{0}=[\mathrm{CuBr}]_{0}=0.313 \mathrm{mmol} ; \mathrm{DMF}=10 \mathrm{~mL} ;[\mathrm{MMA}]_{0}=0.0468 \mathrm{~mol}$.

instruments, USA) at a heating rate of $10^{\circ} \mathrm{C} / \mathrm{min}$ under $\mathrm{N}_{2}$ atmosphere and thermogravimetric analysis (TGA) was carried out using DTG-60 instrument (Shimadzu, Japan) at a heating rate of $10^{\circ} \mathrm{C} / \mathrm{min}$ under $\mathrm{N}_{2}$ atmosphere.

\section{RESULTS AND DISCUSSIONS}

Scheme 1 shows the synthetic route for the preparation of novel MBP-PU-MBP and PMMA- $b$-PU- $b$-PMMA tri-block copolymers. When HMB, was reacted with isocyanate terminated polyurethane, novel 2-methyl-2-bromopropionate terminated polyurethane, MBP-PU-MBP is formed as shown in Scheme 1. When MBP-PU-MBP/CuBr/PMDETA initiating system was used for the polymerization of MMA, ABA type tri-block copolymers were formed where A is PMMA block and $\mathrm{B}$ is PU block. Here the concentration of MBP-PU-MBP was calculated using molecular weight of MBP-PU-MBP obtained through GPC ( $c f$. Table I). Since MBP-PU-MBP has two $\mathrm{Br}$ in its structure, the ratio of MBP-PU-MBP, $\mathrm{CuBr}$, and PMDETA was maintained at 1:2:2 respectively. To select the polymerization temperature, initially the polymerization was carried out at $80^{\circ} \mathrm{C}$, but there was no polymerization and at $90{ }^{\circ} \mathrm{C}$, the polymerization was sluggish. However, in the case of the polymerization at $100^{\circ} \mathrm{C}$, the reaction was not sluggish and hence, $100^{\circ} \mathrm{C}$ was chosen as a reaction temperature for the polymerization.

\section{Controlled Radical Polymerization Studies}

To understand the mechanism of polymerization, effect of changing time on the polymerization of MMA was carried out and the results are presented in Table I. Here, for the calculation of conversion, weight of $[\mathrm{MMA}]_{0}$ was considered 


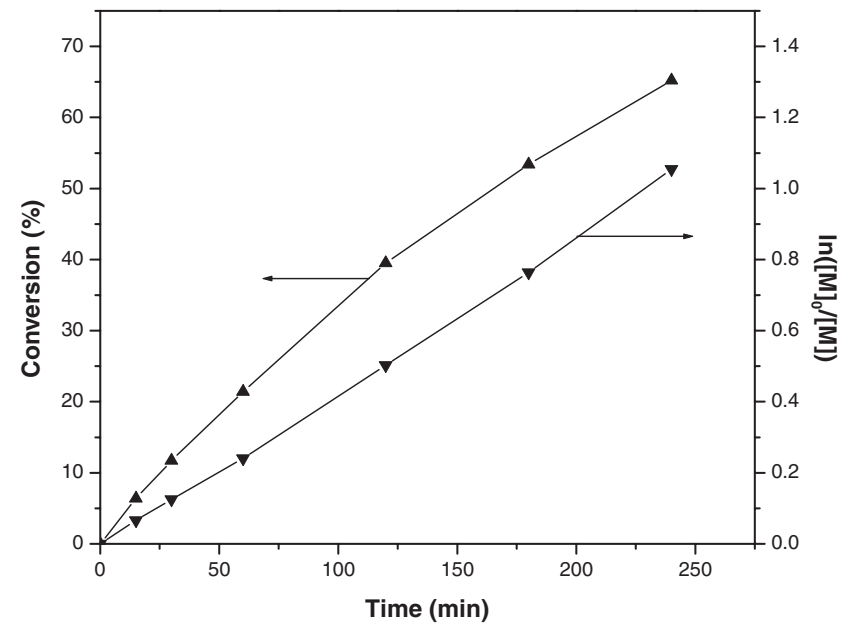

Figure 1. Time-conversion and time- $\ln \left([\mathrm{M}]_{0} /[\mathrm{M}]\right)$ plots for the polymerization of MMA at $100^{\circ} \mathrm{C}$ using MBP-PU-MBP/PMDETA/CuBr initiating system. [MBP-PU-MBP] $0=0.5 \mathrm{~g} \quad(0.5 / 3200=0.156$ $\mathrm{mmol})[\mathrm{PMDETA}]_{0}=[\mathrm{CuBr}]_{0}=0.313 \mathrm{mmol} ; \quad \mathrm{DMF}=10 \mathrm{~mL} ;$ $[\mathrm{MMA}]_{0}=0.0468 \mathrm{~mol}$.

and weight of $[\mathrm{MBP}-\mathrm{PU}-\mathrm{MBP}]_{0}$ was not considered. The weight of MBP-PU-MBP will be same as the polymerization time was increased, so to get the accurate conversion in percentage, the weight of MBP-PU-MBP was not considered. Figure 1 shows polymerization time-conversion and polymerization time- $\ln \left([\mathrm{M}]_{0} /[\mathrm{M}]\right)$ plots for MMA polymerization. As the time increases both conversion and $\ln \left([\mathrm{M}]_{0} /[\mathrm{M}]\right)$ increased which is a typical result in any controlled radical polymerization. The linear increase of $\ln \left([\mathrm{M}]_{0} /[\mathrm{M}]\right)$ shows that the radical concentration is steady throughout the polymerization. Figure 2 shows conversion- $M_{\mathrm{n}}$ and conversion-MWD plots for the polymerization of MMA. As the conversion increases $M_{\mathrm{n}}$ also increases which is clear evidence that the present system follows ATRP mechanism. But the increase of $M_{\mathrm{n}}$ with

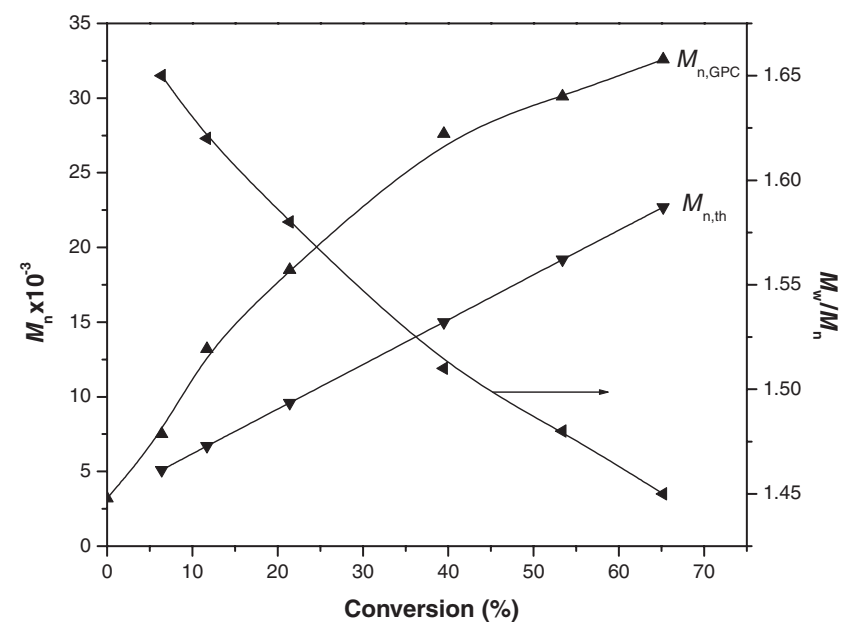

Figure 2. Conversion- $M_{\mathrm{n}}$ and conversion- $M_{\mathrm{w}} / M_{\mathrm{n}}$ plots for the polymerization of MMA at $100^{\circ} \mathrm{C}$ using MBP-PU-MBP/PMDETA/CuBr initiating system. [MBP-PU-MBP] $]_{0}=0.5 \mathrm{~g} \quad(0.5 / 3200=0.156$ $\mathrm{mmol})[\mathrm{PMDETA}]_{0}=[\mathrm{CuBr}]_{0}=0.313 \mathrm{mmol} ; \quad \mathrm{DMF}=10 \mathrm{~mL}$; $[\mathrm{MMA}]_{0}=0.0468 \mathrm{~mol}$. conversion is not linear. Due the presence of inevitable radicalradical termination reactions, ${ }^{5}$ it leads to the loss of linearity in the curves. Similar type curves have been reported in case of ATRP. ${ }^{47-49}$ However, it is interesting to note that MWD decreases with increasing conversion which indicates that the controlled incorporation nature of MMA units take place as the conversion increases. The controlled polymerization nature of the present system can also be understood from the less deviation between $M_{\mathrm{n}, \mathrm{GPC}}$ and $M_{\mathrm{n}, \mathrm{th}}$ in Figure 2 . It is interesting to note that when $-\mathrm{CH}_{2} \mathrm{Br}$ terminated polyurethane was used in our earlier investigation, ${ }^{44} M_{\mathrm{n}, \mathrm{GPC}}$ and $M_{\mathrm{n} \text {,th }}$ values were nowhere near, but in the present case it is comparable. This result shows that 2-methyl-2-bromopropionate terminated polyurethane is better macroinitiator than $-\mathrm{CH}_{2} \mathrm{Br}$ terminated polyurethane. In addition, apparent initiator efficiency ( $\mathrm{f}=$ $\left.M_{\mathrm{n}, \mathrm{th}} / M_{\mathrm{n}, \mathrm{GPC}}\right)$ was also calculated and it is high for POLY 1 and 6 (Table I; 0.68 and 0.69) and low for POLY 2 (0.50). These $f$ values are in agreement with the reported $f$ values of ATRP. ${ }^{15}$ As shown in Table I and Figure 2, the experimental $M_{\mathrm{n}}$ is not exactly matching with the theoretical $M_{\mathrm{n}}$. This may be due to the poor deactivation by $\mathrm{CuBr}_{2}$ which lead to the unavoidable radical-radical termination as side reactions. Similar types of results have been discussed thoroughly by Steenbock et al. ${ }^{5}$ and large deviation of experimental $M_{\mathrm{n}}$ with theoretical $M_{\mathrm{n}}$ has also been reported in the polymerization of MMA through ATRP mechanism. ${ }^{50}$ However the initiator efficiency, f, is more or less high in all the cases. These observations imply that high blocking efficiency ( $\mathrm{f}=M_{\mathrm{n}, \mathrm{th}} /$ $M_{\mathrm{n}, \mathrm{GPC}}$ ) was achieved by the effective transfer of bromine atom from terminal 2-methyl-2-bromopropionate groups of polyurethane to $\mathrm{CuBr}-\mathrm{PMDETA}$ complex.

\section{Spectral Studies}

The ABA tri-block copolymers synthesized were further characterized by FT-IR spectroscopy to confirm the structure. Figure 3 shows the FT-IR spectra of the MBP-PU-MBP and

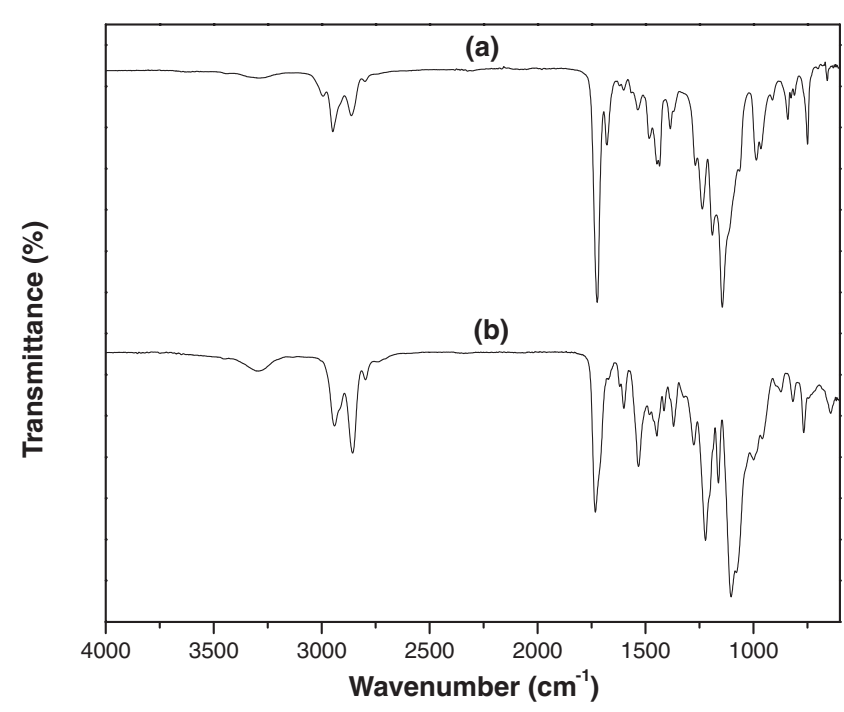

Figure 3. FT-IR spectra of (a) PMMA- $b$-PU- $b$-PMMA tri-block copolymer, POLY 5 and (b) MBP-PU-MBP. 


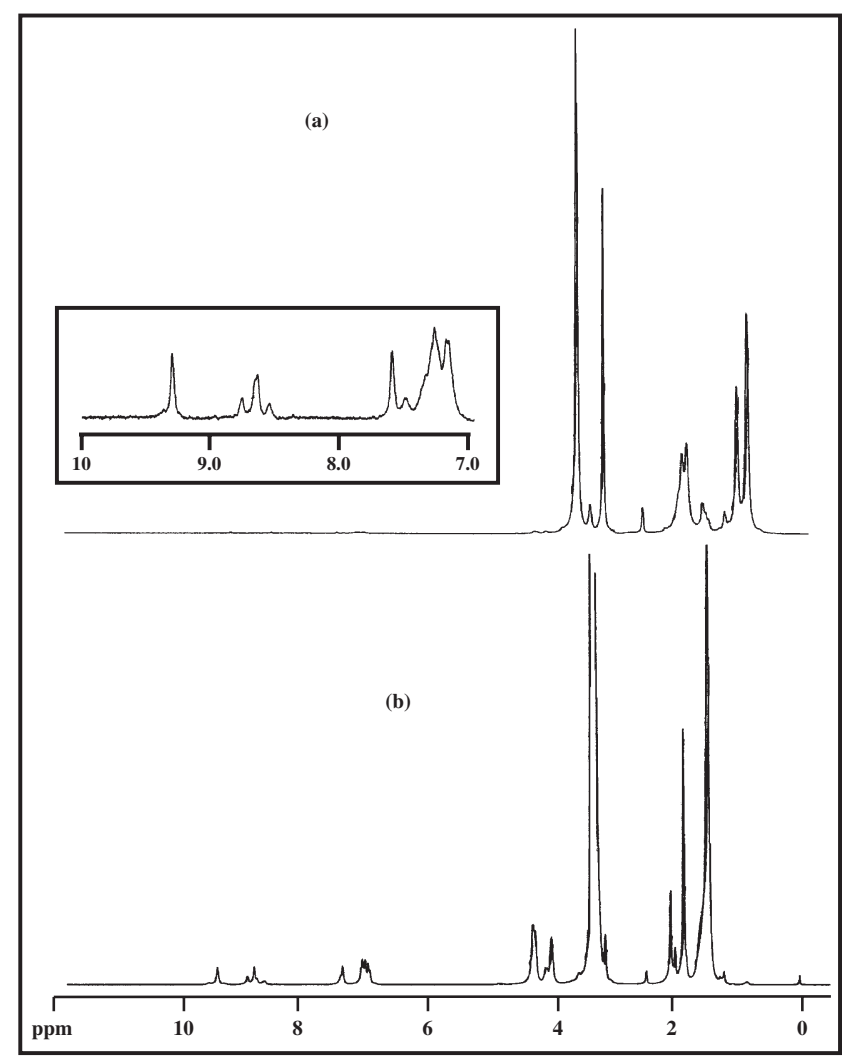

Figure 4. ${ }^{1} \mathrm{H}$ NMR spectra of (a) PMMA- $b$-PU- $b$-PMMA tri-block copolymer, POLY 5 and (b) MBP-PU-MBP.

PMMA- $b$-PU- $b$-PMMA tri-block copolymer obtained at 180 min. (POLY 5 in Table I). In the FT-IR spectrum of MBP-PUMBP (Figure 3(b)), the stretching vibrations of urethane carbonyl group is at $1721 \mathrm{~cm}^{-1}$ and bands at $2787-2949$ $\mathrm{cm}^{-1}$ are associated with $\mathrm{C}-\mathrm{H}$ asymmetric and symmetric stretching of $\mathrm{CH}_{2}$ groups. The band at $1073-1107 \mathrm{~cm}^{-1}$ is due to the stretching of ether $\mathrm{C}-\mathrm{O}-\mathrm{C}$ groups. Stretching and bending vibrations of $-\mathrm{N}-\mathrm{H}$ are observed at $3296 \mathrm{~cm}^{-1}$ and $1532 \mathrm{~cm}^{-1}$ respectively. In the FT-IR spectrum of PMMA- $b$ PU- $b$-PMMA tri-block copolymers (Figure 3(a)), the stretching vibrations of urethane groups and ester carbonyl groups of PMMA blocks are merged and observed at $1721 \mathrm{~cm}^{-1}$. The $\mathrm{C}-\mathrm{H}$ stretching vibrations of methylene groups in $\mathrm{PU}$ and PMMA are observed in the region $2787-2949 \mathrm{~cm}^{-1}$ and $\mathrm{N}-\mathrm{H}$ stretching vibrations are observed at $3300 \mathrm{~cm}^{-1}$. The $\mathrm{C}-\mathrm{H}$ bending vibrations of methylene groups present in $\mathrm{PU}$ and PMMA are observed from $1445 \mathrm{~cm}^{-1}$ to $1595 \mathrm{~cm}^{-1}$. The C-H bending peak of $-\mathrm{CH}_{3}$ groups present in PU blocks (from TDI) and PMMA blocks is observed at $1370 \mathrm{~cm}^{-1}$ in Figure 3(a). The presence of all peaks which corresponds to MBP-PU-MBP in tri-block copolymer and new peaks of PMMA blocks further support the formation of PMMA- $b$-PU- $b$-PMMA tri-block copolymers.

FT NMR spectroscopy was also used to confirm the structure of MBP-PU-MBP and ABA tri-block copolymers. Figure 4(b) and Table II show ${ }^{1} \mathrm{H}$ NMR spectrum and spectral data for MBP-PU-MBP respectively. Phenyl protons and

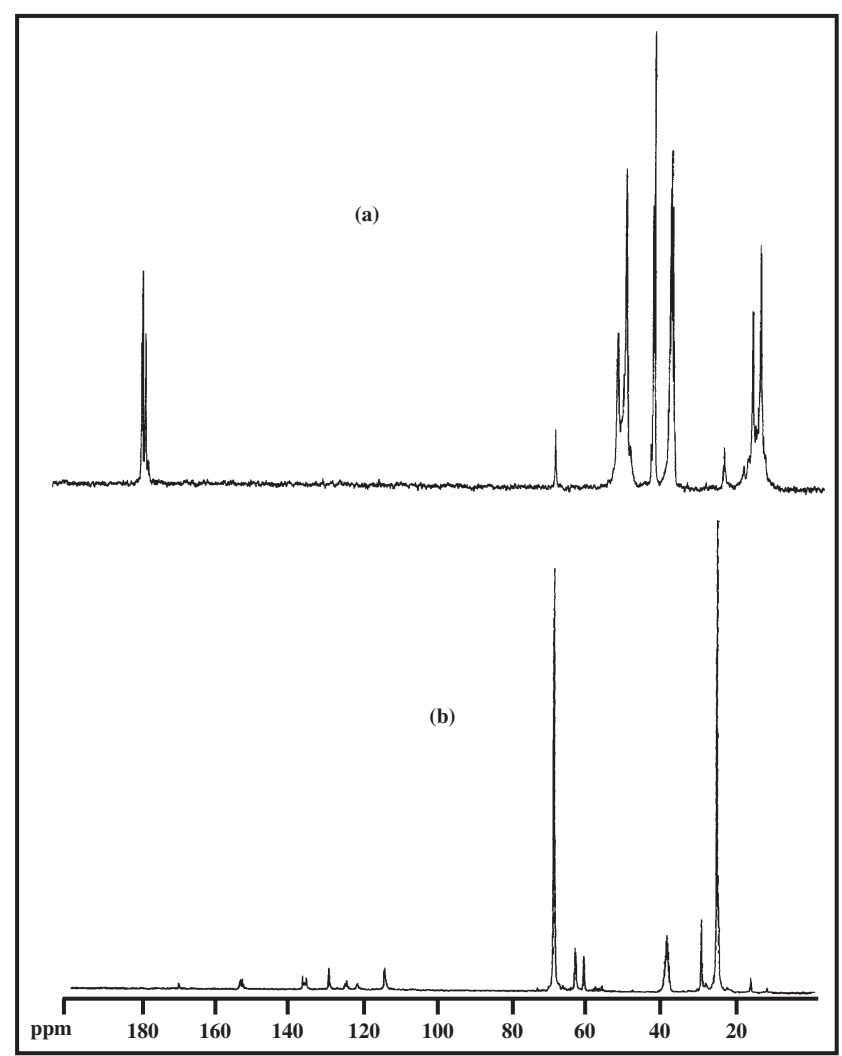

Figure 5. ${ }^{13} \mathrm{C}$ NMR spectra of (a) PMMA- $b$-PU- $b$-PMMA tri-block copolymer, POLY 5 and (b) MBP-PU-MBP.

methyl protons in TDI resonate at 7.03-7.47 ppm and 2.04$2.11 \mathrm{ppm}$ respectively. The $-\mathrm{N}-\mathrm{H}$ protons and the terminal methyl protons of 2-methyl-2-bromopropionate groups present in MBP-PU-MBP appeared at $8.75-9.53 \mathrm{ppm}$ and $1.86 \mathrm{ppm}$ respectively. The peaks correspond to $-\mathrm{CH}_{2}$ and $-\mathrm{OCH}_{2}$ protons of PTMG resonate at $1.5 \mathrm{ppm}$ and $3.15 \mathrm{ppm}$ respectively. The $-\mathrm{OCH}_{2}$ groups present in $\mathrm{HMB}$ and $-\mathrm{OCH}_{2}$ of PTMG which is attached to urethane group appeared at $4.33-4.36 \mathrm{ppm}$ and $4.13 \mathrm{ppm}$ respectively. Figure 5(b) and Table III shows ${ }^{13} \mathrm{C}$ NMR spectrum and spectral data for MBP-PU-MBP respectively. The $-\mathrm{CH}_{2}$ and $-\mathrm{OCH}_{2}$ groups of PTMG appeared at 25.83-26.16 and $69.80 \mathrm{ppm}$ respectively. Aromatic carbons, $-\mathrm{CH}_{3}$ carbons (from TDI) and $-\mathrm{C}=\mathrm{O}$ (from urethane) resonate at $115.14-137.30,17.16$ and $155.56-154.33 \mathrm{ppm}$ respectively. The carbon atoms present in $\mathrm{CH}_{3}, \mathrm{C}-\mathrm{Br},-\mathrm{C}=\mathrm{O}$ and $-\underline{\mathrm{CH}}_{2}$ of terminal 2-methyl-2-bromopropionate groups resonate at $31.40,56.95-58.75,170.81$ and 61.83 ppm respectively. These results show that MBP-PU-MBP was successfully synthesized.

In the ${ }^{1} \mathrm{H}$ NMR spectrum of the ABA tri-block copolymer (Figure 4(a)), the $-\mathrm{N}-\mathrm{H}$ protons of urethane and aromatic protons from TDI appeared at 8.50-9.25 and 7.10-7.53 ppm respectively. The $-\mathrm{CH}_{3}$ protons of PMMA were resonate at $0.84 \mathrm{ppm}, 1.01 \mathrm{ppm}$ and $1.21 \mathrm{ppm}$ which correspond to syndiotactic (rr), atactic (mr) and isotactic (mm) PMMA respectively. ${ }^{51}$ The $-\mathrm{OCH}_{3}$ protons of PMMA were appeared at $3.6 \mathrm{ppm}$. The protons correspond to $-\mathrm{CH}_{2}$ and $-\mathrm{OCH}_{2}$ groups of PTMG were appeared at 1.5 and $3.3 \mathrm{ppm}$ respectively. The 
Table II. ${ }^{1} \mathrm{H}$ NMR data of MBP-PU-MBP and PMMA- $b$-PU- $b$-PMMA tri-block copolymers

\begin{tabular}{|c|c|c|c|}
\hline \multicolumn{2}{|c|}{ MBP-PU-MBP } & \multicolumn{2}{|c|}{ PMMA- $b$-PU- $b$-PMMA tri-block copolymers } \\
\hline${ }^{1} \mathrm{H}$ & $\begin{array}{c}\text { Chemical } \\
\text { Shift } \\
\text { (ppm) }\end{array}$ & ${ }^{1} \mathrm{H}$ & $\begin{array}{c}\text { Chemical } \\
\text { Shift } \\
(\mathrm{ppm})\end{array}$ \\
\hline Terminal Br- $\left(\mathrm{CH}_{3}\right)_{2}$ & 1.86 & $\mathrm{~N}-\underline{\mathrm{H}}$ & $8.50-9.27$ \\
\hline $\mathrm{CO}-\mathrm{O}-\mathrm{CH}_{2}-\mathrm{CH}_{2}^{-}$ & $4.33-4.36$ & $\mathrm{C}_{6} \underline{\mathrm{H}}_{3}\left(\mathrm{CH}_{3}\right) \mathrm{NH}-$ & $7.10-7.53$ \\
\hline $\mathrm{N}-\underline{\mathrm{H}}$ & $8.75-9.53$ & $\mathrm{C}_{6} \mathrm{H}_{3}\left(\mathrm{C}_{2}\right) \mathrm{NH}-\&-\underline{\mathrm{H}}_{2}-$ of PMMA & $1.82-1.90$ \\
\hline $\mathrm{C}_{6} \underline{\mathrm{H}}_{3}\left(\mathrm{CH}_{3}\right) \mathrm{NH}-$ & $7.03-7.47$ & $-\mathrm{C}_{2} \underline{2}$, of PTMG & 1.56 \\
\hline $\mathrm{C}_{6} \mathrm{H}_{3}\left(\mathrm{C}_{2}\right) \mathrm{NH}-$ & $2.04-2.11$ & $-\mathrm{O}-\overline{\mathrm{C}} \underline{\mathrm{H}}_{2}-$ of PTMG & 3.18 \\
\hline$-\mathrm{CH}_{2}$, of $\mathrm{PTMG}$ & 1.5 & $-\mathrm{O}-\mathrm{C}_{2}-{ }_{2}^{-}-\mathrm{NHCOO}$ & 4.08 \\
\hline$-\mathrm{O}-\underline{\mathrm{H}}_{2}-$, of PTMG & 3.41 & $-\mathrm{OC}_{\underline{3}} \underline{3}$ of $\mathrm{PMMA}$ & 3.61 \\
\hline \multirow[t]{5}{*}{$-\mathrm{C}_{2}-\mathrm{O}-\mathrm{CO}-\mathrm{NH}-$} & $4.05-4.13$ & $\mathrm{CO}-\mathrm{O}-\mathrm{CH}_{2}-\mathrm{CH}_{2}-$ & $4.27-4.31$ \\
\hline & & $-\underline{\mathrm{CH}}_{2}-\mathrm{O}-\mathrm{CO}-\mathrm{NH}-\mathrm{C}_{3} \underline{3}$ of PMMA & $4.1185-1.21$ \\
\hline & & $-\mathrm{CH}_{3}$ of PMMA (rr) & 0.84 \\
\hline & & 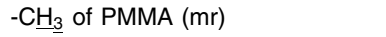 & 1.01 \\
\hline & & $-\mathrm{C}_{\underline{3}} \underline{3}$ of PMMA $(\mathrm{mm})$ & 1.21 \\
\hline
\end{tabular}

Table III. ${ }^{13} \mathrm{C}$ NMR data of MBP-PU-MBP and PMMA- $b-P U-b$-PMMA tri-block copolymers

\begin{tabular}{|c|c|c|c|}
\hline \multicolumn{2}{|c|}{ MBP-PU-MBP } & \multicolumn{2}{|c|}{ PMMA- $b$-PU- $b$-PMMA tri-block copolymers } \\
\hline${ }^{13} \mathrm{C}$ & $\begin{array}{l}\text { Chemical Shift } \\
(\mathrm{ppm})\end{array}$ & ${ }^{13} \mathrm{C}$ & $\begin{array}{l}\text { Chemical Shift } \\
(\mathrm{ppm})\end{array}$ \\
\hline Terminal Br- $\left(\mathrm{CH}_{3}\right)_{2}$ & 31.40 & $\mathrm{C}_{6} \mathrm{H}_{3}\left(\underline{\mathrm{CH}}_{3}\right) \mathrm{NH}-$ & 17.63 \\
\hline $\mathrm{CO}-\mathrm{O}-\mathrm{CH}_{2}-\mathrm{CH}_{2}^{-}$ & 64.20 & $-\mathrm{CH}_{2}$, of PTMG & $43.91-44.77$ \\
\hline $\mathrm{C}_{6} \mathrm{H}_{3}\left(\mathrm{CH}_{3}\right) \mathrm{NH}-$ & $115.14-137.30$ & $-\mathrm{O}-\mathrm{C} \mathrm{H}_{2}-$ of PTMG & 69.49 \\
\hline $\mathrm{C}_{6} \mathrm{H}_{3}\left(\mathrm{CH}_{3}\right) \mathrm{NH}-$ & 17.16 & $-\mathrm{CH}_{2}-$ of PMMA & 17.63 \\
\hline$-\mathrm{CH}_{2}$, of PTMG & $25.83-26.16$ & $>\mathrm{C}<$ of $\mathrm{PMMA}$ & $38.95-40.05$ \\
\hline$-\mathrm{O}-\underline{\mathrm{CH}}_{2}-$ of PTMG & 69.80 & $>\mathrm{C}=\mathrm{O}$ of $\mathrm{PMMA}$ & $175.8-176.8$ \\
\hline$-\underline{\mathrm{CH}}_{2}-\mathrm{O}-\mathrm{CO}-\mathrm{NH}-$ & 61.83 & $-\mathrm{OCH}_{3}$ of PMMA & $50.16-53.42$ \\
\hline $\mathrm{Br}-\underline{-}\left(\mathrm{CH}_{3}\right)_{2}-\mathrm{CO}-\mathrm{O}-$ & $56.95-58.75$ & $-\mathrm{OCH}_{3}$ of PMMA (rr) & 50.16 \\
\hline $\mathrm{O}-\underline{\mathrm{CO}}-\mathrm{NH}-$ of urethane & $153.56-154.33$ & $-\mathrm{OCH}_{3}$ of PMMA (mr) & 51.17 \\
\hline \multirow[t]{5}{*}{$\mathrm{Br}-\left(\underline{\mathrm{CH}}_{3}\right)_{2}-\mathrm{CO}-\mathrm{O}-$ of $\mathrm{HMB}$} & 170.81 & $-\mathrm{OCH}_{3}$ of PMMA (mm) & 53.42 \\
\hline & & $-\underline{\mathrm{CH}}_{3}-$ of PMMA & $16.42-20.68$ \\
\hline & & $-\overline{\mathrm{CH}_{3}}$ of PMMA (rr) & 16.42 \\
\hline & & $-\mathrm{CH}_{3}^{-}$of PMMA (mr) & 17.63 \\
\hline & & $-\mathrm{CH}_{3}$ of PMMA (mm) & 20.68 \\
\hline
\end{tabular}

$-\mathrm{CH}_{3}$ protons of TDI and $-\mathrm{CH}_{2}$ protons of PMMA blocks were appeared in the region $1.8-1.9 \mathrm{ppm}$. Two $-\mathrm{OCH}_{2}$ groups attached to -O-CONH and -O-CO present in 2-methyl-2bromopropionate end groups resonate at 4.11 and $4.31 \mathrm{ppm}$ respectively. The tacticity ratio of PMMA prepared in the present investigation is $\mathrm{rr}: \mathrm{rm}: \mathrm{mm}=56: 37: 7$ which is similar to the reported tacticity ratio (rr:rm:mm, 58:37:5) of PMMA prepared by ATRP of MMA. ${ }^{52}$ In the ${ }^{13} \mathrm{C}$ NMR spectrum of ABA tri-block copolymer (Figure 5(a)), the $-\mathrm{C}=\mathrm{O}$ and $>\mathrm{C}<$ groups of PMMA were appeared in the region 175.8$176.8 \mathrm{ppm}$ and $38.95-40.05 \mathrm{ppm}$ respectively. The $-\mathrm{CH}_{3}$ groups of PMMA resonate at 16.4, 17.6 and $18.4 \mathrm{ppm}$ which correspond to $\mathrm{rr}, \mathrm{mr}$ and $\mathrm{mm}$ respectively. ${ }^{51} \mathrm{The}-\mathrm{CH}_{3}$ groups of TDI was merged with $-\mathrm{CH}_{3}$ groups (rr) of PMMA at $17.6 \mathrm{ppm}$ and $-\mathrm{CH}_{2}$ groups of PMMA block was appeared at 43.91-44.77 ppm. The $-\mathrm{OCH}_{3}$ groups of PMMA were appeared at 50.16, 51.17 and $53.42 \mathrm{ppm}$ which correspond to $\mathrm{rr}, \mathrm{mr}$ and mm respectively. ${ }^{51}$ As the ratio of phenyl carbons from TDI, carbonyl carbons of urethane and ester groups are lower than the PMMA and PTMG blocks, the peaks correspond to these groups are not appeared in the ${ }^{13} \mathrm{C} \mathrm{NMR}$ of the block copolymer. However the peaks correspond to $\mathrm{CH}_{2}$ and $\mathrm{OCH}_{2}$ carbon present in PTMG are appeared at 25.8 and $69.4 \mathrm{ppm}$ respectively. In addition to this, all the peaks correspond to polyurethane and PMMA blocks are present in the ${ }^{1} \mathrm{H}$ NMR, which is a clear evidence for the formation of ABA type triblock copolymers. The molar content of PMMA in the tri block copolymers can easily be found out by comparing molecular weights (obtained by GPC) of MBP-PU-MBP and ABA triblock copolymers which are given in Table I. It can also be found out by peak integration ratio of $-\mathrm{CH}_{2}-\mathrm{CH}_{2}$ - group of PTMO at $1.5 \mathrm{ppm}$ and $-\mathrm{CH}_{3}$ protons of PMMA blocks at 0.84-1.21 ppm through ${ }^{1} \mathrm{H}$ NMR technique, as reported in the literature $^{43}$ and the results are given in Table I. The molar content of PMMA from GPC and ${ }^{1} \mathrm{H}$ NMR techniques are comparatively similar.

\section{Thermal Studies}

The PMMA- $b$-PU- $b$-PMMA tri-block copolymer obtained at $180 \mathrm{~min}$ (POLY 5 of Table I) was further characterized by DSC and the results are presented in Figure 6. All the glass transition temperatures $\left(T_{\mathrm{g}}\right)$ considered in this investigation is the middle point between onset and offset points. The $T_{\mathrm{g}}$ of the polyol segment present in MBP-PU-MBP and PMMA- $b$-PU- $b$ - 


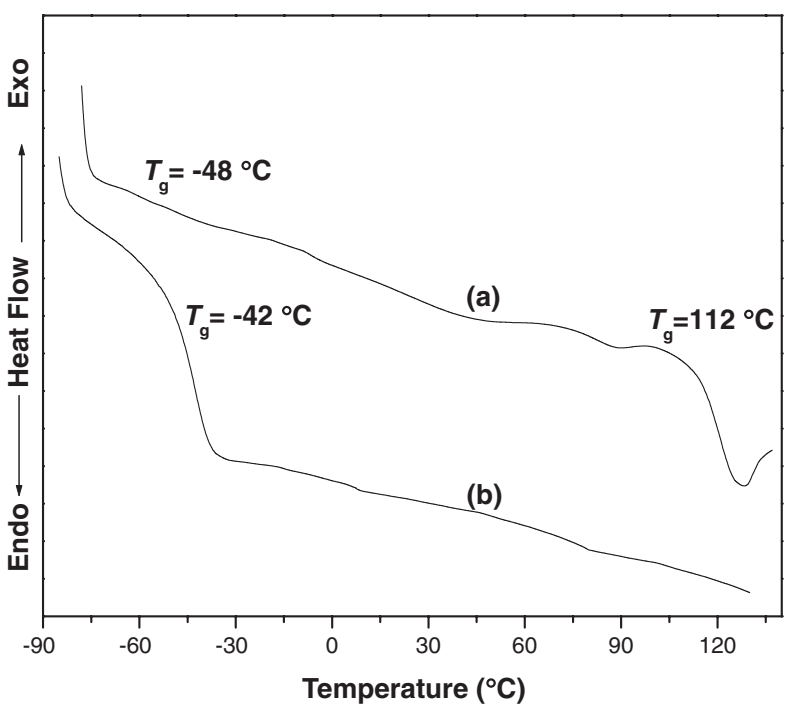

Figure 6. DSC curves of (a) PMMA- $b$-PU- $b$-PMMA tri-block copolymer, POLY 5 and (b) MBP-PU-MBP.

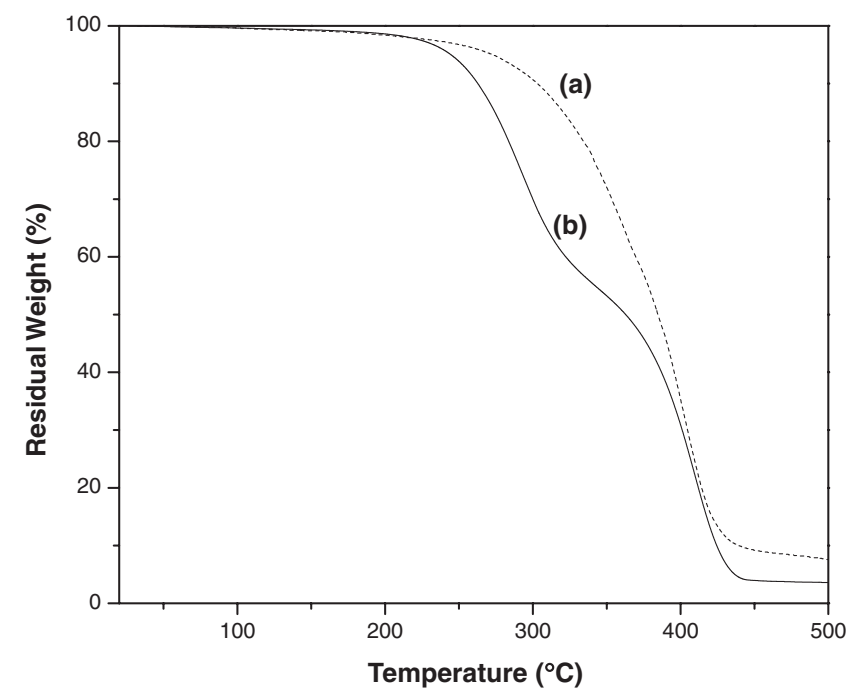

Figure 7. TGA curves of (a) PMMA- $b$-PU- $b$-PMMA tri-block copolymer, POLY 5 and (b) MBP-PU-MBP.

PMMA tri-block copolymers was appeared at $-42^{\circ} \mathrm{C}$ and $-48^{\circ} \mathrm{C}$ respectively. The $T_{\mathrm{g}}$ of the PMMA block was observed at $112^{\circ} \mathrm{C}$ which is similar to the literature value for the tacticity ratio of rr:rm:mm $=56: 37: 6 .^{53}$ Thermal stability of MBP-PUMBP and PMMA- $b$-PU- $b$-PMMA tri-block copolymer (POLY 5 in Table I) was also studied using TGA and the results are presented in Figure 7. MBP-PU-MBP undergoes two-stage decomposition; one is around $284^{\circ} \mathrm{C}$ which is due to the decomposition of the $\mathrm{NHCOO}$ groups and another is around $404{ }^{\circ} \mathrm{C}$ which is due to the decomposition of PTMG blocks. In the case of tri-block copolymers, the decomposition is not in stages but the overall thermal stability of PMMA- $b$-PU- $b$ PMMA tri-block copolymers is higher than the MBP-PU-MBP. Thermal degradation of standard radically prepared PMMA under nitrogen atmosphere proceeds in three steps correspond- ing to the head-to-head linkage $\left(\sim 165^{\circ} \mathrm{C}\right)$, the chain-end initiation from the vinylidene ends $\left(\sim 270^{\circ} \mathrm{C}\right)$, and the step referred to as random scission within the polymer chain $\left(\sim 360^{\circ} \mathrm{C}\right) .{ }^{54}$ Thermal degradation of the polymers synthesized with MBP-PU-MBP/CuBr/PMDETA initiating system occurred around $380^{\circ} \mathrm{C}$ only originating from random scission. This result is a further indication of the absence of abnormal linkages therefore confirming the high regioselectivity and absence of unwanted irreversible termination or transfer reactions. $^{23}$

\section{CONCLUSIONS}

For the first time telechelic 2-methyl-2-bromopropionate terminated polyurethane was successfully synthesized and used further as a macroinitiator to synthesize PMMA- $b$-PU- $b$ PMMA tri-block copolymers through ATRP mechanism. ATRP mechanism during the polymerization was confirmed from the linear increase of time-conversion and time$\ln \left([\mathrm{M}]_{0} /[\mathrm{M}]\right)$ plots. Furthermore, the lack of linearity was observed for $M_{\mathrm{n}}$ Vs conversion curve that may be due to the presence of inevitable termination reactions. $M_{\mathrm{n}, \mathrm{th}}$ of the ABA type tri-block copolymers was found to be more or less similar to $M_{\mathrm{n}, \mathrm{GPC}}$. The molar percentage of PMMA calculated through ${ }^{1} \mathrm{H}$ NMR is matching with GPC results. The results from spectral and thermal methods also confirmed the formation of novel 2-methyl-2-bromopropionate terminated PU and PMMA- $b$-PU- $b$-PMMA tri-block copolymers. As MBP-PUMBP generated narrow MWD tri-block copolymers, this macroinitiator can be used to synthesis different hydrophilic$b$-hydrophobic- $b$-hydrophilic tri-block copolymers. These results will be communicated in near future as a separate article.

Acknowledgment. Authors would like to thank University Grant Commission, New Delhi, India (No. 32-291/2006 (SR) dated $26^{\text {th }}$ February, 2007) for financial support.

Received: December 11, 2007 Accepted: June 20, 2008 Published: July 30, 2008

\section{REFERENCES}

1. M. Szwarc, Nature, 178, 1168 (1956).

2. O. W. Webster, Science, 251, 887 (1991).

3. T. Otsu and M. Yoshida, Makromol. Chem., Rapid Commun., 3, 127 (1982).

4. S. J. Teertstra, E. Chen, D. Chan-Seng, P. O. Otieno, R. G. Hicks, and M. K. Georges, Macromol. Symp., 248, 117 (2007).

5. M. Steenbock, M. Klapper, K. Mullen, C. Bauer, and M. Hubrich, Macromolecules, 31, 5223 (1998).

6. S. Yamago, E. Kayahara, M. Kotani, B. Ray, Y. Kwak, A. Goto, and T. Fukuda, Angew. Chem., Int. Ed., 46, 1304 (2007).

7. S. Yamago, K. Iida, and J. Yoshida, J. Am. Chem. Soc., 124, 2874 (2002).

8. S. Maria, H. Kaneyoshi, K. Matyjaszewski, and R. Poli, Chem. Eur. J., 13, 2480 (2007).

9. S. Yamago, J. Polym. Sci., Part A: Polym. Chem., 44, 1 (2006).

10. T. C. Chung, W. Janvikul, and H. L. Lu, J. Am. Chem. Soc., 118, 705 
(1996).

11. J. Chiefari, Y. K. B. Chong, F. Ercole, J. Krstina, J. Jeffery, T. P. T. Le, R. T. A. Mayadunne, G. F. Meijs, C. L. Moad, G. Moad, E. Rizzardo, and S. H. Thang, Macromolecules, 31, 5559 (1998).

12. K. Matyjaszewski, S. G. Gaynor, and J.-S. Wang, Macromolecules, 28, 2093 (1995).

13. M. Kato, M. Kamigaito, M. Sawamoto, and T. Higashimura, Macromolecules, 28, 1721 (1995).

14. J.-S. Wang and K. Matyjaszewski, Macromolecules, 28, 7901 (1995).

15. M. Destarac, K. Matyjaszewski, and B. Boutevin, Macromol. Chem. Phys., 201, 265 (2000).

16. T. Ando, M. Kamigaito, and M. Sawamoto, Tetrahedron, 53, 15445 (1997).

17. J.-S. Wang and K. Matyjaszewski, Macromolecules, 28, 7901 (1995).

18. M. Senoo, Y. Kotani, M. Kamigaito, and M. Sawamoto, Macromolecules, 32, 8005 (1999).

19. V. Percec, B. Barboiu, A. Neumann, J. C. Ronda, and M. Zhao, Macromolecules, 29, 3665 (1996).

20. T. E. Patten, J. Xia, T. Abernathy, and K. Matyjaszewski, Science, 272, 866 (1996).

21. Z. Xue, S. K. Noh, and W. S. Lyoo, Macromol. Res., 15, 302 (2007).

22. Z. Xue, B. W. Lee, S. K. Noh, and W. S. Lyoo, Polymer, 48, 4704 (2007).

23. C. Granel, P. Dubois, R. Jérôme, and P. Teyssié, Macromolecules, 29, 8576 (1996).

24. E. L. Grognec, J. Claverie, and R. Poli, J. Am. Chem. Soc., 123, 9513 (2001).

25. Y. Kabachii, S. Kochev, L. Bronstein, I. Blagodatskikh, and P. Valetsky, Polym. Bull., 50, 271 (2003).

26. P. Lecomte, I. Draiper, P. Dubois, P. Teyssié, and R. Jérôme, Macromolecules, 30, 7631 (1997).

27. W. A. Braunecker, Y. Itami, and K. Matyjaszewski, Macromolecules, 38, 9402 (2005).

28. Y. Kotani, M. Kamigaito, and M. Sawamoto, Macromolecules, 32, 2420 (1999).

29. K. L. Beers, S. G. Gaynor, K. Matyjaszewski, S. S. Sheiko, and M. Moller, Macromolecules, 31, 9413 (1998).

30. D. Wang, Z. Peng, X. Liu, Z. Tong, C. Wang, and B. Ren, Eur. Polym. J., 43, 2799 (2007).

31. S. Motala-Timol and D. Jhurry, Eur. Polym. J., 43, 3042 (2007).

32. Y. Gao, H. Li, and X. Wang, Polym. Int., 56, 976 (2007).

33. J. Hedrick, M. Trollsas, C. Hawker, B. Atthoff, H. Claesson,
A. Heise, R. Miller, D. Mecerreyes, R. Jerome, and P. Dubois, Macromolecules, 31, 8691 (1998).

34. Z. Huang, Y. Zhang, H. Li, and Y. Liu, Appl. Catal. A, 332, 192 (2007).

35. D.-Z. Liu, J.-H. Hsieh, X.-C. Fan, J.-D. Yang, and T.-W. Chung, Carbohydr. Polym., 68, 544 (2007).

36. M. J. Santander-Ortega, A. B. Jódar-Reyes, N. Csaba, D. BastosGonzález, and J. L. Ortega-Vinuesa, J. Colloid Interface Sci., 302, 522 (2006)

37. H. Cho, D. Chung, and J. Aeongho, Biomaterials, 25, 3733 (2004).

38. G. S. Kwon and K. Kataokab, Adv. Drug. Delivery Rev., 16, 295 (1995).

39. K. Kataoka, H. Atsushi, and Y. Nagasaki, Adv. Drug. Delivery Rev., 47, 113 (2001).

40. M. Szycher, "Szycher Handbook of Polyurethanes." CRC Press LLC, Florida, 1999.

41. K. Tharanikkarasu and G. Radhakrishnan, J. Appl. Polym. Sci., 66, 1551 (1997).

42. K. Tharanikkarasu and G. Radhakrishnan, Eur. Polym. J., 33, 1779 (1997).

43. Y. Higaki, H. Otsuka, and A. Takahara, Polymer, 47, 3784 (2006).

44. H. Verma and K. Tharanikkarasu, Polym. Int., 57, 226 (2008).

45. R. N. Keller, H. D. Wycoff, and L. E. Marchi, Inorg. Syn., 2, 1 (1947).

46. D. M. Haddleton, C. Aterson, P. J. Derrick, C. B. Jasieczek, and A. J. Shooter, Chem. Commun., 683 (1997).

47. S. Venkataraman and K. L. Wooley, Macromolecules, 39, 9661 (2006).

48. S. B. Lee, A. J. Russell, and K. Matyjaszewski, Biomacromolecules, 4, 1386 (2003).

49. A. Ramakrishnan and R. Dhamodharan, Macromolecules, 36, 1039 (2003).

50. B. Reining, H. Koul, and H. Hocker, Polymer, 43, 3139 (2002).

51. K. Matsuzaki, T. Uryu, and T. Asakura, "NMR Spectroscopy and Streoregularity of Polymers," Japan Scientific Societies Press, Tokyo, 1996, p. 57.

52. H. Uegaki, Y. Kotani, M. Kamigaito, and M. Sawamoto, Macromolecules, 30, 2249 (1997).

53. W. Wunderlich, in "Polymer Handbook" J. Brandrup and E. H. Immergut, Ed., John Wiley \& Sons, Toronto, 1989, p. V/78.

54. K. Hatada, T. Kitayama, N. Fujimoto, and T. J. M. S. Nishiura, J. Macromol. Sci., Pure \& Appl. Chem., A30, 645 (1993). 